\title{
Med politiet i 'virkeligheden': Reality-tv og kriminalitet
}

\author{
Af Ib Bondebjerg
}

\begin{abstract}
Kriminalstoffet på to bliver ofte anklaget for at spekulere $i$ vore lavere instinkter, og med reality kommer vi tattere end nogensinde på samfundets bund og det utrettelige politi, som har til opgave at opretholde lov og orden. Artiklen gennemgär en lang rekke af de senere års kriminalprogrammer og diskuterer dokumentarismens former med en serlig belysning af astetik, retorik og synsvinkel i undergenrerne " reality magasin« og »reality soap«. Lars Engels' serie »Historier fra en politistation« tages op til sarlig debat, fordi Engels - vanen tro - arbejder med en mindre iscenesattelse og ukommenteret virkelighedsgengivelse, end vi finder det $i$ andre sreality soapsu.
\end{abstract}

»Man jager et bæst, men fanger et menneske« (Politimand fra det virkelige Rejseholdet)

Krimistoffet, hvad enten det er i fakta- eller fiktionsform, er et af de ældste og mest populære områder for historier i både litteratur- og mediegenrer. Grundlæggende er det, med henvisning til denne artikels indledningsmotto fra en virkelig politimands mund, forholdet mellem bæstet i os alle og det menneskelige, forholdet mellem hverdagens trygge rutiner og tragediens angst, gru og melodrama, der fascinerer. Krimistoffet og krimihistorien gør os alle til detektiver i forhold til andre og os selv, og til ligeså fascinerede iagttagere af forbrydelsens skjulte årsager og psykologi. Afdækningen af de økonomiske, sociale, psykiske, erotiske mv. kræfter, der i ekstrem form driver det meste kriminalitet, vidner om det tynde lag mellem civilisation og destruktion, mellem den private back stage og den offentlige maske, mellem socialt fællesskab og individuel galskab eller egoisme, mellem liv og død. Den moderne medievirkeligheds krimistof er gjort af samme stof som det, der skaber thriller og horror, tragedie og melodrama - konfrontationen med bagsiden og de tragiske og stærkt emotionelle sider af den menneskelige natur og sociale orden.

Krimifiktionen og kriminalstoffet på tv har altid kæmpet med anklagen for spekulation i de laveste instinkter og for at bruge menneskelig ulykke og tragedie til underholdning for den laveste fællesnævner. Samtidig har mange program- og receptionsanalyser beskæftiget sig med det problematiske i, at kriminalitet gives så høj en profil i medierne, så seerne får en forkert fornemmelse af kriminalitetens omfang og karakter i forhold til i virkeligheden (jf. f.eks. Fishman \& Cavender 1998 og Schlesinger \& Tumber 1994). Bestemte typer af kriminalitet er mere spektakulære end andre, og derfor har især de kommercielle stationer en tendens til at fokusere udelukkende på røverier, vold og seksuelle forbrydelser. Kritikken af programmerne er også, specielt i USA og England, gået på den problematiske symbiose mellem journalistik og politi, hvor den kritiske distance måske går fløjten, og politiarbejdet romantiseres og bliver urealistisk. Det gælder måske ikke mindst for de nyeste former for reality-tv, som fra USA, England og Tyskland er vandret ind i dansk tv i 90'erne, som arvtagere til ældre dokumentariske genrer, og helt generelt for krimiserien på tv. På den anden side måtte også krimilitteraturen kæmpe længe for sin status som kunst. Det samme gælder helt åbenlyst både for kriminalitet som dokumentarisk stofområde og fiktivt tv-serie materiale. Det er da også ganske påfaldende, at netop opbruddet fra den traditionelle public service monopol-kultur og den øgende kommercielle konkurrence mellem mange kanaler har styrket krimistoffet i prime time inden for både dokumentarismen og fiktionen. Men trods den kritik, der har været rejst, så er krimistoffet i sig selv lige så legitimt og vigtigt som andre stofområder, men rummer naturligvis lige så mange tendenser og kvalitetsforskelle som andre programmer.

Inden for de seneste 5 år har man kunnet studere kriminaliteten og politiet i arbejde på de fleste kanaler $\mathrm{i}$ både flere dokumentariske former og fle- 
re fiktive udgaver via en ganske markant national programsatsning. Dertil skal lægges at en betydelig del af de importerede amerikanske og engelske programmer også falder i denne kategori. På fiktionssiden har både DR, TV2 og TV3 satset ganske stort med henholdsvis Rejseholdet (2000-), Strisser på Samso (1996-) og Skjulte spor (2000-), serier der kombinerer en ny actionstil med lokale kvaliteter og historier og et betydeligt dokumentarisk islæt i den grundige beskrivelse af politiarbejde. Rejseholdet bygger endog direkte og erkendt på autentiske historier, og serien har af samme grund rejst en etisk debat om, hvor langt og tæt på man kan gå i skildringen af ofte ganske nye sager ${ }^{1}$.

I samme periode har reality-tv og andre dokumentariske former fokuseret ligeså hyppigt på politiets arbejde og på kriminalitet. Reality-magasiner har siden Politirapporten (Weekend TV, 1985, se Søndergaard og Hjarvard 1988) meget ofte drejet sig om kriminalitet: Kriminalmagasinet (DR, 19851990), Uopklaret (DR, 1990-), Forsvundne danskere (DR, 1999-), Station 2 (TV2, 1993), Efterlyst (TV3, 1997-) og 48 timer (TVDanmark, 1998-). Inspirationen kommer for public service tv's vedkommende ikke mindst fra engelsk tv, f.eks. BBC's Crimewatch (1984-) eller det tyske ZDF-magasin Actenzeichen XY - ungelöst (opr. 1967, genoptaget 1990-), mens de mere kommercielle stationer oftest læner sig op af de mere actionprægede amerikanske magasinformer, f.eks. NBC's Unsolved Mysteries (1987-), Fox's America's Most Wanted (1988-) Cops (1989-), ABC's American Detectives (1991-) og Fox's Manhunter (1994) (se Bondebjerg 1996/2000 og Fishman \& Cavender 1998). Men også dokumentariske serier, hvor man uden den journalistiske indpakning følger politiets arbejde, har været stærkt fremme, og også for visses vedkommende omdiskuteret. Af danske eksempler kan nævnes Dola Bonfils tidlige forløber Politiet $i$ virkeligheden (1986, 3 afsnit), financieret af SFC og DR og sendt i DR, DR's moderne opfølgere, Stromer på stenbroen (DR, 1998, 6 afsnit) og ikke mindst Lars Engels' mammut-føljeton Historier fra en politistation (DR, 1-13, 2000-2001) og endelig TV3's Storbystromer (1998, 6 afsnit).

\section{De dokumentariske grund- genrer og kriminaliteten}

Reality-tv er 90'ernes nye tendens indenfor tv-dokumentarismen, og som et produkt af en kommercialiseret, konkurrencebaseret tv-kultur bevæger den sig dels tættere på den intime hverdag og de mere tabuiserede kulturfelter, som f.eks. kriminalitet og sex. Autenticiteten i grundmaterialet, dvs. virkelige mennesker og virkelige begivenheder, og den iscenesatte autenticitet, dvs. valg af retoriske $\mathrm{og}$ visuelle former, der understøtter og simulerer her-og-nu oplevelse i en live virkelighed, deler reality-tv med hele den dokumentariske tradition. Der er heller ikke noget nyt i fokuseringen på 'soft news' og 'human interest' og 'sensational' eller 'other news' (Langer 1998). Det er fænomener, som siden pressens opkomst og journalistikkens fødsel har præget den journalistiske og dokumentariske fortælling om virkeligheden i dele af pressen, fortrinsvis ugeblade, billedblade og i formiddagspressen.

Den svenske medieforsker Mats Ekström har i en artikel om forskellige kommunikationsformer i journalistik (Ekström 2000) defineret tre former for journalistisk formidling: journalistik som information, journalistik som fortelling og journalistik som attraktion. I den forste form er journalisten en informant, der giver information til den engagerede samfundsborger og fortæller om virkeligheden gennem konfrontation af kilder og journalistiske spørgsmål og svar. I den anden form bliver journalistik til en dramatisk fortælling om begivenheder, konflikter eller personer, og vores holdning til disse nyheder antager en næsten fiktiv seers position, og personerne bliver karakterer eller aktanter i dette drama. I den tredje form får journalistikken karakter af den spektakulære fremvisning, som forandrer os til måbende, nysgerrige, voyeuristiske tilskuere til en virkelighed, der åbner forbavsende, skræmmende etc. skjulte kræfter og dimensioner. På samme måde taler John Langer i sin bog om 'tabloid television' og 'the other news' som en særlig slags journalistiske fortællinger, der fokuserer på: 'the especially remarkable', 'victims', 'communities at risk' eller 'ritual, tradition and the past' (Langer 1998:35) - netop de felter som fascinerer os ved kriminalitetsstof indenfor både fiktion og non-fiktion.

Snarere end at tale om den nyere tv-dokumentarisme og reality-tv som bare en degradering eller et forfald indenfor journalistik og tv-dokumentarisme må man altså tale om reality-tv som del af en lang dokumentarisk og journalistisk forhistorie. Tv-journalistikken og tv-dokumentarismen har for længst taget denne form for skildring af virkeligheden op, centreret omkring 'human interest' 
og med inddragelse af hverdagsliv og almindelige menneskers oplevelser og problemer. Vi har allerede være inde på det tidlige tyske kriminalmagasin (jf. ovenfor), og på amerikansk tv har vi f.eks. Real People (1979-, jf. Jerslev 2000). Allerede i 1973 sendte den amerikanske tv-station PBS den første egentlige reality-tv-serie, An American Family, hvor amerikanske seere kunne følge en tilsyneladende almindelig families udvikling og gradvise indre opløsning gennem et år (jf. Jeffrey Ruoff 1998: 286 ff). Som i nyere reality-tv-serier følges her en gruppe personer gennem længere tid og blandingen af den autentiske virkelighed og den observerede dagligdag, og den dramatiske, narrative sammenklipning og selve det forhold, at historien udviklede sig så afslørende og dramatisk, som den gjorde, gør serien til en reality-tv forløber.

Tv-dokumentarismens og journalistikkens historie har altså en række eksempler på forløbere for den moderne reality-tv. De forskellige reality-tv genrer opfinder ikke en ny dokumentarisme, men videreudvikler og kombinerer elementer fra den allerede eksisterende, dokumentariske tradition på nye måder og ved at gå tættere og tættere på virkeligheden. Tv-dokumentarismen i Danmark har sin egen historie, som naturligvis er influeret af filmdokumentarismen, journalistikkenogradiodokumentaren. Men grundlæggende kan man tale om 5 tv-dokumentariske former i den hidtidige danske og internationale tv-historie fra 60'erne og frem: den dybdeborende journalistiske tv-dokumentarisme, den observerende dokumentarisme, den dramatiserede dokumentarisme, den refleksive og poetiske dokumentarisme og reality-tv ${ }^{2}$. Reality-tv som grundform henter i virkeligheden $\mathrm{i}$ sine underformer elementer fra $\mathrm{i}$ hvert fald de tre første dokumentariske formater, mens den refleksive-poetiske dokumentarisme har en forsvindende lille plads i tv-dokumentarismens historie. Der synes ganske simpelt ikke at være særlig plads til denne meget personlige og æstetiske eksperimenterende form, som ofte kun findes på de meget sene sendetidspunkter på mere smalle kanaler som f.eks. DR2.

Den dybdeborende journalistiske tv-dokumentar er først og fremmest præget af epistemisk autoritet, dvs. en søgen efter sandheden i en sag eller et problem og med en tiltro til, at denne kan findes via journalistisk graven i kilder og modsætninger. Dvs. det er en sagsorienteret form, hvor den grundlæggende dramatiske struktur er efterforskningens, med journalisten som detektiven. Den har en lineær struktur og er retorisk argumentatorisk bygget op, således at den rejser en række klare spørgsmål og søger at give en række lige så entydige svar, en klar konklusion og en løsning. Genren vælger oftest offentlige sager af stor almen og politisk betydning, men kan også fokusere på mere almene 'human interest' forhold, der har politiske aspekter. Den kan bruge dramatisering og rekonstruktion og også visuel symbolik og effekter, men oftest anvendt for at angive spring mellem udsigelses- og beretterniveauer, dvs. som visuel retorisk niveaumarkering. Et meget typisk eksempel inden for kriminalitetstemaet og med politiet i en central rolle er Steen Baadsgaard og Jørgen Petersens berømte og omdiskuterede to dokumentarprogrammer om den såkaldte Pedal Ove-sag om hustrumord, Dømt for mord (1990) og Politiets blinde oje (1991). Her bliver journalisten en privatdetektiv på sporet af et justitsmord og dårligt politiarbejde og seerne dermed del af en eftersøgningsproces i en sag, som endte med genoptagelse og frifindelse. Udsendelsen har - samtidig med at den er tung af journalistisk information og dybdeboring - også alle fortællingens og det spektakulæres kvaliteter: det er et trekantsdrama med stærke følelser og rimeligt sensationelle afsøgninger af en skjult sammenhæng og verden bag den trivielle provins- og hverdagsoverflade.

Den observerende dokumentarisme dukker som allerede sagt op på dansk og internationalt tv i 60'erne, men den udvikler sig til en af de helt centrale dokumentariske tv-former i 80'erne, specielt via DR-dokumentargruppen og f.eks. Lars Engels' programmer om livet på samfundets sociale skyggeside. Det er en form som ligesom moderne reality-tv ofte går meget tæt på det personlige, private og på de sider af hverdagslivet, som ofte ikke fremvises i offentligheden. Ligesom reality-tv har disse former da også været anklaget for at være social pornografi og voyeurisme for Over-Danmark på Under-Danmarks bekostning (se Bondebjerg 2001). Det er en form, som kun har en meget svagt markeret epistemisk autoritet, dvs. som ikke søger nogen klart defineret sandhed, men snarere viser en kollektiv livsverden frem for at give den stemme i en offentlighed, som ofte udgrænser den. Den observerende dokumentarisme tager derfor heller ikke bestemte sager op, men beskriver enkeltindivider (portræt) eller hyppigst grupper, ofte knyttet til institutionaliseret liv (fængsler, mandehjem, kvarterer, beboelseskvarterer). Som form har genren en episodisk mosaikstruktur, og den bygger sjældent på lineær 
dramaturgi. Hvis den følger en lineær struktur, så er det, fordi den afspejler en bestemt tidsstruktur eller en tidsligt struktureret hverdagsvirkelighed (en natlæges vagt, livet på en hospitalsafdeling etc.). Der anvendes derfor også sjældent dramatisering $\mathrm{i}$ form af traditionel fiktiv dramaturgi, men dramaturgien kan skabes via selve virkelighedsdramaet eller via en dramatisk montage af episoderne. Formen har normalt ikke nogen stærk visuel symbolik og visuel iscenesættelse, og hvis det forekommer, er det meget svagt og meget selektivt. Prototypen på den slags observerende dokumentarisme med politiet og kriminaliteten som emne er dels Dola Bonfils Med politiet i virkeligheden (1986, 3 afsnit), der på etnografisk vis følger arbejdet på en politistation og Lars Engels' moderne opfølgning af dette tema i Historier fra en politistation (2000-2001, 13 afsnit).

Den refleksive-poetiske dokumentarisme er så sjælden på tv, at den ikke skal uddybes her. Det er en dokumentarform, hvor selve virkelighedsudsigelsen og iscenesættelsen gøres til det centrale i fremstillingen. Heller ikke den dramatiserede dokumentarisme skal beskrives nærmere her. Den havde især sin storhedstid i 70'erne og 80'erne i form af dramadok (dvs. fiktive, men typiske cases iscenesat som dokumentarisme) eller docu-drama (dvs. en faktisk historie udført som rent fiktivt, realistisk drama med stærkt markeret virkelighedsreference). Det er faktisk en form, som i dag meget stærkt minder om visse elementer i reality-tv. De moderne former for reality-tv bygger i sine grundformer på elementer i både den journalistiske dokumentar, den observerende dokumentar og den dramatiserede dokumentar. Men der lægges nu meget stærkere vægt på emotionel og dramatisk iscenesættelse af hverdagsliv og human interest.

\section{0'ernes reality-tv}

90'ernes reality-tv er ikke noget nyt fænomen, men alligevel markerer de nye reality-genrer på flere punkter en nyudvikling af forskellige undergenrer, hvor dramatisering og iscenesættelse af hverdagslivet antager klart forskellige former. Samtidig er omfanget af den voyeuristiske overvågning markant intensiveret, f.eks. i Big Brother, hvor kameraer og mikrofoner døgnet rundt filmer personer, indespærret i 100 dage. Der er i hvert fald tre undergenrer i det, som man under ét har kaldt 90'ernes reality-tv: reality-magasin, reality-serie og reality-show.
Reality-magasinet er den mest journalistiske af reality-tv formerne. Her er der tale om et fast magasinprogram med en journalistisk studievært, der fremlægger forskellige cases, som regel om kriminalitet, ulykker eller/og dramatiske redningsaktioner og hændelser. Ulykkesmagasinet, f.eks. det legendariske engelske 999 eller det ligeså legendariske amerikanske Rescue 911, har i udgangspunktet den oplysende effekt at fortælle om ulykker i hverdagen, for at seeren kan lære at undgå dem, men samtidig at skildre professionelle redningsfolks heroiske indsats eller almindelige menneskers heroiske evner i krisesituationer. Dramatiserede rekonstruktioner spiller en vigtig rolle. Kun få danske stationer har udviklet selvstændige formater her, idet man har vist de udenlandske. Men TV3 lavede dog Alarm 112.

Kriminalmagasinet har normalt som sit primære formål at sætte fokus på uløste forbrydelser eller give generel oplysning om kriminalitet og politiarbejde, og til dette benyttes bl.a. dramatiske rekonstruktioner, som inddrager seeren som detektiv, og som dermed forlener programmet med nogle af den fiktive krimis kvaliteter. Det tidligste danske eksempel er Politirapporten (Weekend TV, 1985), og DR's omtrent samtidige første forsøg i genren, Kriminalmagasinet (DR, 1985-1990), som både i form og indhold er et eksempel på en fornyelse af reality-magasinet. Efterfølgeren Uopklaret (DR, 1990-) er en meget mere traditionel efterligning af den tyske forløber på området og de engelske BBC-forbilleder. Det samme gælder TV2's Station 2 (TV2, 1993-), mens Efterlyst (TV3, 1998-2000, 70 episoder) lægger sig tættere op ad amerikanske modeller. Endelig kan man også nævne DR's reality-magasin Forsuundne danskere (DR, 1999), som iscenesætter journalisten som detektiv, men inddrager politi og andre offentlige myndigheder. I alle disse former for reality-magasiner kombineres en tydelig, autoritativ studievært og interviews med både professionelle og almindelige mennesker, således at de dramatiske og melodramatiske indslag er indlejret og framet af en oplysningsideologi, i hvert fald i public service tv-versionerne (se om dette Bondebjerg 1996).

Reality-serien (docu-soap) er karakteristisk ved at have føljetonens eller seriens narrative præg. Ligesom i den fiktive føljetonform følger vi en gruppe autentiske personer igennem en længere, fortløbende fortalt historie, sommetider knyttet til en bestemt lokalitet, institution, en bestemt arbejds- 
plads, en bestemt fritidsbeskæftigelse eller nogle af de store ritualer i vores hverdag som f.eks. fødsel, bryllupper og død. Der behøver dog ikke altid at være en fortløbende historie og persongruppe, idet man også kan have en fast lokalitet og persongruppe, hvortil knyttes forskellige nye personer pr. afsnit. Dvs. her får formen en slags seriepræg, idet den samme historie gentages med variationer i hvert afsnit. Reality-serien kan rumme en autoritativ speak og også markant visuel stil eller scenografi, men vil hyppigt i lange passager have karakter af observerende dokumentarisme med svagere eller stærkere anvendelse af visse dramaturgiske træk. Inden for politikriminalitetsområdet er Dola Bonfils klassiske, observerende dokumentariske udsendelse Politiet $i$ virkeligheden en forløber for reality-serien, og det hidtil mest kvalitetsprægede, nyere bud er Lars Engels' store 13 timers beretning fra Station 1 i det hårde inner-city miljø i København, Historier fra en politistation. Egentlig fortsætter Engels her bare sin traditionelle observerende stil (jf. Bondebjerg 2001), men der finder alligevel et fokusskifte sted, som er interessant i forhold til hans tidligere udsendelser. Samtidig er det kun i kvalitet og production value, man kan se forskel på denne Engels-serie og reality-serier som Stromer på stenbroen og Storbystromer.

Den sidste grundform er reality-showet. Her er der tale om programmer, der konstruerer en konkurrencepræget ramme omkring udvalgte, almindelige mennesker, som skal leve sammen eller kæmpe mod hinanden efter ganske bestemte regler og under ganske bestemte fysiske rammer og betingelser. Ofte spilles der på den sociale mekanisme, der bestemmer, hvordan man inkluderes i en gruppe eller ekskluderes, dvs. at alle de mest centrale socialpsykologiske mekanismer, som behersker både familieliv, kærlighedsliv og arbejdsliv synliggøres i et iscenesat show-agtigt og dramatisk forløb, f.eks. Robinson Ekspeditionens (TV3) spektakulære og eventyragtige drømmeverden eller Big Brothers (TVDanmark) intense, næsten psyko-terror-agtige overvågning døgnet rundt. Disse gamereality-shows, som har trukket store seertal verden over, og også været spektakulære mediebegivenheder, har også former, som minder mere om den klassiske, dramatiserede dokumentarisme og dens iscenesatte eksperimenter med socialt, psykologisk og kulturelt sigte. Det ser man f.eks. i BBC's The 1900 House (sendt på dansk TV2), som er en historisk rekonstruktion af livet i et victoriansk hus fra år 1900 og et socialt eksperiment, der tester en nutidig families evne til at overleve på fortidens betingelser. Her er faktisk tale om underholdende, informativ og levendegjort socialhistorie.

\section{Seeren som lænestolsdetektiv og strømer: krimimagasinet}

Kriminalitetsstoffet i monopol-tv perioden før 1988 var ikke fremtrædende via specielle programtyper, men indgik naturligvis i den løbende nyheds- og aktualitetsformidling. Der synes ikke at være nogen entydig tendens til en jævn stigning i omfanget af politi- og kriminalstof fra 1965-1997 på DR. If. Hjarvards undersøgelse af tv-nyhedsindslagenes fordeling på emner (Hjarvard 1999: 263ff) så var procenten af indslag om politi på DR således: 1965 (4.2\%), 1974 (2.7\%), 1984 (3.6\%), 1990 (1.6\%), 1997 (8.9\%). Retsvesen og kriminalitet udgjorde til sammenligning: 1965 (12.5\%), 1974 (9.1\%), 1984 (10.5\%), 1990 (7.9\%) og 1997 (9.5\%). Men samtidig sker der det, at de mange mere kommercielle kanaler har dette stof højere prioriteret i deres nyhedssendinger, således at stoffet samlet set vokser. Endelig er det i 90'erne alle de nye reality-programmer eksploderer og dermed også slår tilbage i nyhedsformidlingen, som ofte laver optakt til og videreformidler de sager, som er kommet frem i reality-magasinerne. TV2 havde i 1997 en markant højere andel politi- og kriminalitetsnyheder end DR, nemlig $12.5 \%$ og $11.9 \%$ (mod DR's $8.9 \%$ og 9.5\%), og TV3 ligger klart højere igen med $10.9 \%$ og $15.4 \%$. Vi ser altså i nyhedsformidlingen det samme billede som ved den trykte presse: de kommercielle stationer har som tabloid-aviserne en meget klarere sensationel profil og dominans på kriminalitet, mens public service stationerne er mere selektive og tilbageholdende på samme måde som omnibus-aviserne.

Men udover kriminalstoffets vækst på de halveller helkommercielle kanaler så er det reality-tv programmerne, der repræsenterer den markante nye udvikling i forholdet mellem kriminalitet/politi, medier og seer. Det var da også karakteristisk nok den første kommercielle tv-station i Danmark, Weekend TV som i 1985 lancerede det første reality-kriminal-magasin, Politirapport (Hjarvard \& Søndergaard 1988: pp. 258-263). Iflg. Hjarvard \& Søndergaards analyse er programmet direkte inspireret af BBC's Crimewatch og det tyske Achtenzeichen $X, Y$ - ungelöst, dvs. det lægger sig ikke, som 
det ellers er karakteristisk for de senere kommercielle stationer op ad de amerikanske genrer på området. Redaktøren Kim O'Stritt har sagt (Hjarvard \& Søndergaard 1988: 258) at man overvejede et »kritisk« eller et »service« program i forhold til politiet, men at man altså valgte et service program, hvor man samarbejdede med politiet, og han hævder også at progammet var et af de mest populære (475.000 seere og ca. 400-600 opringninger ved hver udsendelse). Det var altså en serie som ved sit eftersøgningskoncept både fascinerede og aktiverede de danske seere.

Strukturen i programmet er ganske identisk med den vi ser i det tyske og engelske program, og som senere går igen i de fleste af de danske: først en intro-signatur og en studieværts intro med siden sidst og update om forrige programs cases og nye spor. Derefter følger en række nye hovedsager, ca. 3 pr. gang med studieværts-intro, studieinterviews med politifolk og andre vidner og en rekonstruktion, hvorefter der appelleres direkte til seeren. Sagerne er typisk enkeltmandsforbrydelser eller bandeforbrydelse som røveri, vold, indbrud, voldtægt, bankkup etc. Sagerne er direkte og utvetydigt rettet mod opklaring og jagt på spor og gerningsmand, og der er ingen bredere social, psykologisk eller anden kritisk eller perspektiverende synsvinkel. Og rekonstruktionerne er intense, dramatiske gengivelser af forbydelsens øjeblik, så tæt på som muligt. TV-stationen og journalistikken bliver altså her ikke en virkelighedens vagthund, ikke en uafhængig instans, men et serviceorgan for politiets arbejde og leverandør af virkelighedsstof, der forvandler seeren til en detektiv og strømer hjemme i den trygge lænestol. Hjarvard \& Søndergaards dom er da også hård: det er et effektivt og godt lavet program, men »sagt ligeud er programmets næsegruse beundring for politiet og kolportering af statsmagtens opgaver i deres mest forsimplede former en hån mod enhver kritisk journalistik« (Hjarvard \& Søndergaard 1988: 263).

Konkurrencen fra Weekend TV fik samme år DR til at gå på banen med et reality-magasin, Kriminalmagasinet, der fik Kim Vejrup som studievært, men konceptet er helt forskelligt fra Weekend TV's. Kriminalmagasinets æstetiske struktur og retorik er baseret på on location optagelser (forskudt live eller ægte live), dvs. både programmets studievært og øvrige journalister er ude og snakke med de involverede på stedet i de forskellige lokale miljøer. Der er altså ikke noget studie, der ligner en mellemting mellem et nyhedsstudie og en politistation. For det andet er konceptet $i k k e$, at seeren skal være med til at opklare uopklarede forbrydelser, men at kaste socialt og psykologisk lys over røvere og deres ofre. Som det hedder på programmet hjemmeside (www.dr.dk/krimi):

- Kriminalmagasinet går i direkte nærkontakt med ofre og gerningsmænd

- Hver 14. dag stiller vi skarpt på kriminalitet i Danmark.

- Programmets vært Kim Vejrup opsøger de steder, hvor forbrydelserne er begået.

Programmets intro slår da også fast, at det er et program om »skyld, ret og moral«, og at man vil gå tættere på sagen for at se på konksekvenser og mennesker.

Dette særlige koncept betyder også, at der ikke bruges egentlige, gennemførte rekonstruktioner i programmet. Man opsøger stederne og kilderne og bruger det visuelle materiale, som måtte være til rådighed, f.eks. autentiske optagelser fra overvågningskameraer (ov-cam) i banker og butikker. I den udsendelse, som er lagt til grund for denne artikel, er fokus på røvere og deres ofre i anledning af særlig mange røverier i en periode i Århus. Optakten kommer fra Kim Vejrup i Århus, og der klippes efter introen til ov-cams fra en butik, der er blevet røvet, og derefter til interview med de to ekspedienter, en mand og en kvinde, om deres oplevelse af overfaldet og psykiske eftervirkninger. Herefter følger i komprimeret form og via udsendt journalist en beretning om en række andre røverier (Grill, Bilka, Danske Bank), hvor journalisten i VO og ledsaget af ov-cams eller reportage-cam fra stedet beretter om facts og personer i disse sager. Dernæst opsummerer Kim Vejrup og interviewer kriminalchefen i Århus for at få klarhed over, om de mange røverier er et udtryk for, at »Århus er ved at udvikle sig til et dansk Chicago « med planlagt og organiseret kriminalitet, eller om det er en statistisk tilfældighed. Interviewet handler om de mulige baggrunde og årsager til røverier.

Herefter handler resten af programmet stort set blot om røverne og deres ofre, dvs. programmet veksler mellem interviews med nogle af ofrene fra de røverier, vi har set, og et ganske dybtgående interview med en anonymiseret røver (man ser ikke hans ansigt), som har fået sin dom, men som fortæller historien fra røverens vinkel. Denne historie 
rummer også en mere social dimension, idet der i røverens rehabilitering indgår en konfrontation med ofret, som også beskrives. Der følges op med et interview med Bilka-købmanden, hvis røver aldrig er blevet fundet, og som blev så psykisk ødelagt og angst af oplevelsen, at han måtte afhænde sin butik og søge andet arbejde i en anden by. Der klippes frem og tilbage mellem offer-interviewene og røver-interviewet og mellem journalisten i marken og Kim Vejrup som overordnet reportagestemme, der sammenfatter og bringer tingene op på et mere overordnet og generelt plan, bl.a. ved at søge at kortlægge røveriernes natur og karakter og forholdet mellem de små og de store fisk $\mathrm{i}$ interviewet med kriminalchefen.

Kriminalmagasinet kan karakteriseres som det tætteste, vi kommer på dansk tv indenfor selvstændigt, kritisk og perspektiverende reality-tv om kriminalitet. Efterfølgeren Uopklaret er til gengæld et langt mere traditionelt journalistisk magasin. Udsendelsen markerer helt ud i logoet, som er tv-avisens øje, at der her er tale om et selvstændigt, journalistisk magasin på linje med de øvrige nyhedsmagasiner som f.eks. Horisont, Profilen osv. Men hele grundlaget for udsendelsen er samarbejdet med politiet - og dermed ikke en fri journalistisk position. Det er den garvede studievært Hans Georg Møller, der er ankerperson, og i selve introen, hvor han ankommer til studiet, der ligner et reporterkontor med arkivskabe, lægges der distance til at smelte totalt sammen med politiet. Man ser en mand løbe til en telefonboks for at ringe, Hans Georg Møller tager den og siger: »Nej, De skal ikke ringe til os, men til Politiet«. Der markeres altså en distance til politiet, og tv står som selvstændig formidler mellem politi og seere. Det samme gælder, om end i mindre grad for TV2's program Station 2 (som både i studieindretning og titel er tættere på at imitere tv-stationen som en politistation), mens TV3 med deres Efterlyst (1997-) indgår total symbiose studiemæssigt og diskursivt med politiet: studiet er omdannet til en arbejdende politistation.

Uopklaret er bestemt ikke noget sensationssøgende program, og selvom der benyttes dramatiske rekonstruktioner, så er de næsten demonstrativt nedtonet og pædagogisk tilrettelagt og rummer aldrig nogen eksplicit vold. De politipersoner, der benyttes, er også meget langt fra de fiktive, amerikanske tv-seriers betjente og privatdetektiver. Det er stive embedsmænd og jakkesæt, der taler, og ofte søger journalisten med sine spørgsmål at afbøde seernes eventuelle frygt. Det gælder ikke mindst for den valgte udsendelse, der fokuserer på kvindemord og voldtægt. Her er det især to uopklarede kvindemord, der står i centrum. De to rekonstruktioner af de to kvindemord er bygget ens op: først en optakt fra studiet ved studieværten, så overtages sagen af en anden reporter, som kommenterer sagen VO under rekonstruktionen. Selve rekonstruktionen er bygget op, så man følger ofrets sidste færden med nøje angivelse af tid og sted, ved hjælp af ure, grafiske kort etc. og sådan, at selve mordet kun høres svagt off screen. I det hele taget er både denne rekonstruktion og den følgende næsten uden statister, som man kommer tæt på som personer, dvs. rekonstruktionen søger at minimere den filmiske identifikationseffekt og dermed den mere psykologiske fascination og spænding. Til gengæld understreges altså det faktuelle via en journalistisk VO og ved at benytte rekonstruktionen snarere som illustration end som selvstændigt visuelt udtryk.

Udover journalist VO er der også vidne VO under en del af rekonstruktionen, og til sidst følges også morderens formodede flugtrute. Efter selve rekonstruktionen følger et endnu mere pædagogisk resumé af sagens facts og en opfordring til at ringe ind og give oplysninger. Umiddelbart herefter interviewes den politimyndighed, som har sagen. Han prøver at give et psyko-portræt af morderen og opfordrer meget stærkt alle med de mindste oplysninger om at henvende sig og lægger stærkt moralsk pres på familie og pårørende om ikke at holde sig tilbage. Der loves anonymitet $\mathrm{og}$ vidnebeskyttelse. Via programmet og politiet lægges der altså maksimalt pres på seerne og borgernes pligt til at melde andre og medvirke til opklaring af forbrydelser. Til gengæld søger lederen af Københavns Politis drabsafdeling, som er den interviewede politimand i disse indslag, ved journalistens hjælp bevidst at undgå frygt-effekten: Drabene er ikke udtryk for en øget fare eller stigning i kvindemord, og man skal ikke som kvinde være bange for at færdes, blot man gør det med omtanke.

TV2's pendant Station 2 går en del videre i den retoriske og æstetiske opbygning af udsendelsen og studiemiljøet. Generelt øges fornemmelsen af spænding og live-karakteren, bl.a. ved at vi i tilbagevendende underkapitler, På patrulje og Efterlyst følger Michèle Bellaiche og endog studieværten 
direkte ude i marken, på gerningsstedet eller opklaringsarbejdet, eller man følger med politiet på udrykning og razzia. Udsendelsens logo er også utroligt hurtigt og actionpræget klippet. Action- og live-præget er der på en måde også lagt direkte op til i studiet og ved studie-introen. Station 2's studie er meget tættere på et arbejdende politikontor, og Jes Dorph Petersen og Niels Brinch lægger også op til at gå i marken fra starten, hvor de annoncerer, at et af dagens temaer, de unges amfetaminmisbrug, vil blive belyst gennem et uanmeldt besøg på et af Københavns diskoteker. Studiet er direkte linket til dette sted via live storskærm i baggrunden. Det er altså journalisten, der laver 'simuleret' razzia, og vi er dermed tættere på iscenesættelsen af journalisten som detektiv og opklarer, således som vi kender det fra de amerikanske formater.

Det første indslag om ung bandeaktivitet blandt 2. generationsindvandrere i Høje Taastrup understøtter det overordnede tema, som binder hele denne udsendelse sammen: unge stoffer og kriminalitet. Bandetemaet belyses ved VO og grafik og ved interviews i marken med politiet og de unge. Og umiddelbart efter dette første indslag går vi fra logoet På patrulje direkte til Michèle Bellaiche live fra Østerbro, hvor et knivstiksdrama har udspillet sig mellem unge indvandrere og danskere, afsluttet med af MB ser direkte ind i kameraet og opfordrer folk til at give oplysninger. Herefter gås der tilbage til studiet, hvor Jes Dorph runder af og laver overgang til ecstasy-indslaget med besøg på diskotek. Det stigende antal overfald begrundes bl.a. med stofmisbrug. Det underbygges af interview i studiet med en tidligere narkoman og kriminel, der nu er afvænnet, men kan fortælle om sagen set fra den kriminelles synsvinkel. Der er også interview med en læge om virkningen af ecstasy og farerne ved det. Indslaget er meget varieret, idet der klippes mellem studie, interviews, optagelser fra diskoteket (live/forskudt). Redaktionen afprøver en ny type test, drug-wipe, som på få sekunder kan afsløre om en diskoteksgæst er stofpåvirket. Resultatet viser at 8 ud af 10 var positive. Det er både studieværten Jes Dorph Petersen og Michèle Bellaiche, der her er live ude i marken og dermed understreger TV2 konceptets lidt mere actionprægede stil. Men der bruges også i programmet helt traditionel journalistisk retorik i form af traditionelle journalistiske udsagn til kameraet, ekspertinterviews og erfaringsinterviews.

Det er også i denne udsendelse vi finder et af de meget sjældne politikritiske indslag i disse reality kriminalmagasiner. Sagen handler om den måde, politifolk undersøges på, når de er mistænkt for ulovlig embedsførelse eller korruption, nemlig at det bl.a. er politiet selv, der undersøger politiet. Programmet fortæller relativt nøgternt om systemet og sætter spørgsmålstegn ved det udfra en enkelt case, og til sidst nævnes det, at ml. 10-20 om året suspenderes fra tjeneste på grund af sager.

I På patrulje indslagene belyses en konkret kriminalsag eller et alment samfundsmæssigt problem med kriminelle aspekter, som seeren placeres i en oplevelsesposition i forhold til, en oplevelsesposition som svarer til den dokumentariske live-reportage med journalisten og politiet ude i marken. Reportagen fra diskoteket og fra knivstiksgerningsstedet er et eksempel, men der kommer senere i slutningen af udsendelsen en hel række løst sammenkædede indslag af samme type, hvor vi følger politiet (i denne udsendelse fra Svendborg) ud til en påkørsel ved en flugtbilist, til husspektakler, til indbrud hos et ældre ægtepar og til indfangning af en spritbilist, der kører race i stærkt beruset tilstand. Indslagene har ingen anden funktion end at vise politiets og kriminalitetens hverdag.

Den anden slags direkte indslag, Efterlyst, er i modsætning til På patrulje indslagene klassiske indslag, der opfordrer seeren til at være aktiv lænestolsstrømer ved at ringe ind og give oplysninger om uopklarede forbrydelser. Disse indslag fylder imidlertid ikke ret meget i den samlede udsendelse, men der er dog tre indslag med $\mathrm{MB}$, som direkte fra et gerningssted beretter om sagen og taler med politiet og de involverede og også opfordrer til at ringe til et bestemt nummer om de forskellige sager. Der bruges i disse indslag ikke rekonstruktioner, dvs. den journalistiske diskurs dominerer her.

Endnu en type indslag indgår som fast punkt i Station 2, nemlig Museums-arkivet, hvor berømte historiske sager genfortælles af en ældre betjent fra et studie, der emmer af gammel engelsk Sherlock Holmes stil. Sagen genfortælles fra studie med henvisning til kilder og dokumenter, eller med VO til levende og still-billeder. I denne udsendelse er det en sag om hypnose som baggrund for mord på to politibetjente.

Som helhed er Station 2 det mest varierede af de danske kriminalmagasiner og på en gang mere solidt journalistisk og langt mere spektakulært iscenesat end Uopklaret. Man kan i forhold til Eks- 
tröms kategorier sige, at Station 2 lægger vægt på den dramatiserede og den spektakulære journalistik i sine live-indslag, hvor seeren oplyses ved at opleve og være på stedet, mens omvendt det mere traditionelt informative både ligger i f.eks. det politikritiske indslag, i museumsindslaget og i Efterlyst indslagene, som rummer de traditionelle invitationer til seeren om at gå i aktion og blive aktiv. Men programmet er et ægte public service tv-koncept i den forstand, at det spektakulære og fortællende ikke består i fiktivt, dramatiserede og realistisk udfoldede rekonstruktioner af uopklarede forbrydelser, men af dokumentarisk-reportageagtig iscenesættelse af den aktive journalist som seerens forlængede virkelighedsdetektiv. DR har en meget neddæmpet journalistisk profil og en meget neddæmpet rekonstruktion, mens TV2 iscenesætter den journalistiske rolle mere dramatisk.

TV3's Efterlyst er til gengæld spektakulært og dramatisk, både ved sin iscenesættelse af journalistikken og tv-stationen og ved en spektakulær og dramatisk iscenesættelse af rekonstruktionerne. Vi er i nærheden af det amerikanske forbillede i f.eks. Fox Networks Americas Most Wanted, som også er det program, programmets danske hjemmeside har link til. Studiet er iscenesat som en stor arbejdende politistation med et journalistisk podie i midten og en skranke bagest, hvor centrale politipersoner (i den udvalgte udsendelse en fra Rejseholdet og en fra Drabsafdelingen) sidder klar med overordnede kommentarer. Billedoptakten er en stærkt dramatisk montage, og lige i hælene på denne træder studieværten Tina Riising ind i studiet som en anden 'mediestar' og starter udsendelsen. Hun appellerer stærkt til seerne: $d u$ kan hjælpe politiet, og de tre hovedsager: voldtægt, kvindemord og brutalt overfald på taxachauffør introduceres med korte dramatiske rekonstruktionsklip. Inden dagens udsendelse går i gang, resummeres udviklingen siden forrige udsendelse, og i en samtale med de to politi-eksperter slås det fast, at seernes henvendelse sidste gang har bidraget meget væsentlig til at bringe en opklaring nærmere.

De enkelte indslag har på mange måder samme struktur som DR's Uopklaret, men selve rekonstruktionen er anderledes dramatiseret og mere realistisk og spektakulær i sine filmiske virkemidler. Der bruges konsekvent mystiske blåtonede farvetoner, der skaber en stemning af uhygge, det understreges af klassisk underlægningsmusik og et relativt højt og markant lydregister i øvrigt, bl.a. de involveredes råb, stønnen osv. Selve mordene, overfaldene eller voldtægten gengives meget realistisk. Men samtidig bruges pædagogisk sammenfatning af tid og sted og andre facts og et signalement af den formodede gerningsmand.

Programmet varer inklusiv reklamer ca. 1 time. Reklameblokkene rummer ofte indslag om andre krimiprogrammer og samtidig selvpromovering af Efterlyst, bl.a. deres internetside, men også et længere indslag om reality-tv i andre dele af verden, hvor der gives tal på, hvor mange sager seerne har været med til at løse (f.eks. $20 \%$ i Norge). Der argumenteres også direkte for realismen, som skal hjælpe på seernes erindring, og endelig lanceres programmet som »mere end et almindeligt tv-program - det giver seerne mulighed for at påvirke deres egen virkelighed «. Retorikken bliver nok her en anelse overdrevet, for hvad TV3's program leverer er først og fremmest dramatiske rekonstruktioner, som spiller på modsætningen mellem seerens trygge lænestolsvirkelighed og risikosamfundet derude, som man på afstand kan engagere sig i. Men der er ikke spor selvstændig journalistik eller reel oplysning og information. Det er et fascinations-kick kombineret med fornemmelsen af at kunne være strømer i andre folks liv. Det er ganske vist 'vores hverdag' og 'det kunne ske for os alle', men kriminalitetsbilledet er i dette program som i alle andre særdeles begrænset til de mest spektakulære personforbrydelser. Det er billigere end fiktionskrimier, men ikke halvt så godt og perspektivrigt på et psykologisk, socialt og æstetisk plan. Det er discount-dokumentarisme for at skaffe seere.

\section{Med politiet på arbejde: Reality-serier}

Reality-serier (eller docu-soaps) blander, som navnet siger, den observerende dokumentariske genre med den fiktive soaps mere narrative og melodramatiske skildring af lange hverdagsforløb og dramaer. De er reality-tv's melodramatiske og spændingsladede svar på krimifiktionen. Reality-serier er den form for reality-tv, som har fyldt mest på programfladen fra $1995 \mathrm{og}$ frem, men det er ikke en genre, som har givet anledning til så voldsomme medieomtaler som reality-shows. I mange henseender er de da også blot fortsættelser af den observerende dokumentarismes klassiske former, men med en vis tendens til tabloidisering 
af temaer og miljøer især på de kommercielle kanaler. Mens f.eks. TV2 lavede den meget sobre og gribende serie Fødegangen, og DR f.eks. lavede Ful i Magasin og Bladet (om Ekstrabladet) og dermed fokuserede på arbejdspladser og almene hverdagserfaringer, så slog TV3 fat på lidt pink voyeurisme med Stripperkongens piger. Docu-soaps om politiet som arbejdsplads blev også lanceret både på DR med Stromer på Stenbroen, som beskriver hverdagen hos Nørrebro Nærpoliti, og TV3's Stromer på Stenbroen.

Strategien bag docu-soap som genre fremgår for DR's vedkommende af den interne »Docusoap-Bibel « ${ }^{3}$ :

- Den gode docu-soap er bundet af et handlingsforløb i nutiden

- Der skal være interaktion mellem de medvirkende

- God casting af de medvirkende er essentiel (dvs. de skal kunne fungere i deres hverdag selv om kameraet er til stede)

- Der skal være genkendelighed

- Der skal være både indre og ydre historier og handlinger, dvs. der skal være en række historier med set up, konflikter etc., og der skal via de løbende handlingstråde også være afsluttede handlingsforløb

- Der skal laves grundig research, lige så grundig som ved en spillefilm, så man sikrer sig at personerne og historierne holder. Man skal altså ikke bare filme den rå virkelighed.

- Der må dog ikke vere virkelighedsforvrengende instruktion, dvs. handlinger eller samtaler eller reaktioner må ikke provokeres frem af tv-holdets medarbejdere.

Det er altså ganske tydeligt, at genrensinstitutionelle profil er nøje og bevidst fastlagt som baseret på virkelige personer og på en så vidt muligt ikke instrueret, men alligevel narrativt organiseret præsentation af det valgte virkelighedsudsnit. Men i forhold til det journalistiske perspektiv er vi her i den fortællende diskurs, delvist i den spektakulære, mens det informative som retorisk og journalistisk form er trukket stærkt i baggrunden. I DR's bibel peges der da også på 'casting' og 'fiktionsresearch', dvs. ikke en research, som går på historiens aktualitet eller sandhedsværdi, men på dens kvalitet som menneskeligt drama og hverdagsfortælling: holder historien og dens karakterer til netop denne hybridgenre. Man kan jo i normal journalistik og nyhedsformidling ikke i så høj grad styre, om dem man skal tale med faktisk slår igennem på skærmen. Men i docusoaps er det netop denne kvalitet ved de virkelige personer, der bliver afgørende. Der lægges da også i de uddybende kommentarer i DR's bibel op til, at historierne skal være sjove og interessante, men først og fremmest have menneskelig dybde og identifikation, og der lægges en klart dramaturgisk model frem: »En dokusoap skal fungere som en stor fisk: et godt bid, en krop med godt kød og en hale, som kan give et godt slag til slut. Alle de historier, der præsenteres i en dokusoap skal også være små fisk på en række med bid, kød og slag med halen« (DR-Bibel om dokusoap).

Der arbejdes altså med en slags ydre lineær og dramaturgisk model, hvor de samlede handlingstråde og små historier er passet ind, og hvor hver af de små historier spejler den overordnede store historie. Der skal altså både i det samlede forløb og i hvert af de små underforløb stræbes mod at have både set up, cliff hanger og pay off. Og der arbejdes i castingen af personer til historien helt klart med at finde hoved- og bipersoner, der supplerer hinanden og giver gode forskelle og mulighed for variation og samspil. Der opfordres endvidere i biblen til brug af levende og varieret kameraføring, hvor der veksles mellem total, nær og supernær og så vidt muligt undgås for mange gennemsnitlige halvtotaler. Der anbefales også brug af flotte mellemlægsbilleder, som både kan fungere som rumorientering, men også som stemningsskabende overgange mellem delafsnit og historier. Endelig peges der på, at man skal være omhyggelig med reallyd og nærlyd i overgange. Der er derimod ikke formuleret regler for brug af underlægningsmusik.

Ser vi nu ud fra denne bibel på de to typiske reality-serier fra DR og TV3, der har politiet i centrum, er der både markante ligheder og markante forskelle. DR's Stromer på stenbroen (tilrettelægger Christian Andersen) ${ }^{4}$ er opbygget som en føljeton i 6 afsnit, der skildrer livet på en lille nærpolitistation på Nørrebro og de klienter og kriminelle, de møder. Programmet annonceres meget personificeret af DR-speakeren, som inviterer seerne til at møde Jesper, Michael, Alice, Claus og Bo (navne på stationens betjente) på deres arbejde. De gøres til almindelige mennesker i øjenhøjde. Logoet, som følger umiddelbart efter annonceringen, er 
en elektronisk manipuleret billedcollage, som ikke så meget lægger vægt på action og drama, selvom der er udrykningsblink og forbryderjagt, men mere på de enkelte betjente fanget i kontaktsituationer af relativt fredelig, hverdagsagtig karakter. Dermed lægger seriens visuelle signatur en slags forventningsspor om hverdagsrealisme, ikke action og drama som f.eks. i den amerikanske fiktionsserie Hill Street Blues, hvis visuelle signatur den ellers minder om. Det er den nære, lokale og menneskelige dimension, der lægges vægt på.

Strukturelt og dramaturgisk set er udsendelsen bygget op som en historie om en dag, der rummer 4 underhistorier: Jespers færdselsundervisning i en børnehave, Michael, Claus og Bos civilklædte razzia mod et lokalt bordel, Jespers farvel til stationen fordi han skal forflyttes, og et nødopkald om assistance i forbindelse med husspektakler. Der veksles altså mellem det meget trivielle og hverdagslige og det lidt mere dramatiske. Der puttes endvidere en personlig, menneskelig vinkel ind i forhold til de enkelte betjente, dels via Jespers afsked, men også ved små indslag fra deres samtaler og interaktion på stationen. Der er en klar pay off på den kriminalistiske hovedhistorie om bordellet og også de to andre historier. Men det er den første, der er den tydeligste: den starter i det helt uvisse og ender med et gennembrud i opklaringen $o g$ betjentenes opdagelse af bagmanden og hans netværk. Endelig bruger programmet en klar cliff hanger-effekt, både i skiftet mellem de enkelte historier og i selve afslutningen. Der krydsklippes hele programmet mellem børnehaven, bordelbesøget, livet på stationen, således at de enkelte underhistorier fortælles i små brudstykker, indtil de alle nærmer sig afslutningen. Og her lægges der så op til næste afsnit, hvor det annonceres, at man vil få at vide, om betjentene nu også nåede ud til husspektaklerne i tide, og hvordan Alice og en anden kvindelig betjent går undercover i en sexsag.

En overordnet VO guider os igennem programmet med en række regibemærkninger og kommentarer. Men ellers er det et stykke virkelighed, der udfolder sig selv og delvis følger tidsrytmen og den dags begivenheder. Serien er dog bevidst klippet sammen på en sådan måde, at både det dokumentariske og det dramatisk-fiktionsagtige tilgodeses. Det gælder også for TV3's Storbystromer, som er lavet for TV3 af Freeport film med Peter Enggaard Rewentlow som tilrettelægger. Her er der dog som helhed gjort en del mere ud af den billedmæssige side, og det afspejler sig også i de historier, der indgår, at vi her er på den hårde Station 1, som også er rammen om Lars Engels' Historier fra en politistation. Den visuelle signatur og programmets logo er betydeligt mere actionpræget og tættere på District Hill optakten end DR-programmet.

Men som både i DR-programmet og den amerikanske krimiserie præsenteres betjentene som karakterer med navns nævnelse på skærmen og $\mathrm{i}$ introen, hvor en $\mathrm{VO}$, som ligger over hele programmet, fokuserer på de fire hovedhistorier: Diana på Narkoovervågning, René på udrykning til uroligheder på Strøget, Halvor som fanger en biltyv, og Michael som tænker tilbage på Scandinavian Star katastrofen. Men faktisk rummer afsnittet flere underhistorier, også nogle som går mere på betjentenes personlige situation. Bl.a. Diana som skal tilbage til Løgstør politi, to på patrulje i Tivoli, graffitimaler der går amok ved bus, biljagt efter en spritbilist. Der er altså præcis den samme struktur med et overordnet dramaturgisk forløb og en række underhistorier, som der krydsklippes mellem, og som har hver deres dramaturgiske forløb.

Den visuelle og øvrige æstetiske iscenesættelse er mere pågående end i DR-udsendelsen. Der bruges således varieret underlægningsmusik, som klart tjener til at skabe den rette stemning under de forskellige historier: det dramatiske og lidt uhyggelige og det mere afslappede og almindelige. Endelig bruger programmet systematisk lyriske mellemlægsbilleder ved større sekvensskifte, således at vi dels får en lille pause $\mathrm{i}$ historierne, men også sådan at billederne af byen oppefra ved nat eller $\mathrm{i}$ dagslys placerer historierne i tid og rum. Også her bruges musikalsk underlæg. Det dramaturgiske forløb blander samtidig åbenlyst et dramaturgisk kontrastprincip (fra den ene type historie til den anden) i klipningen, men samtidig er de forskellige historier styret af en tids- og døgnrytme: programmet er en sammenfatning af formodentlig to døgn på stationen.

I disse to reality-serier om politiets arbejde siger det sig selv, at der ikke er nogen kritisk distance til politiet og deres arbejdsmetoder. Det er grundlæggende et observerende og registrerende program på linje med de øvrige arbejdspladsprogrammer. Men der er indbygget en klart etisk dimension i skildringen af de kriminelle, som tilfældigvis kommer i kameraets søgevinkel. De er får alle elektronisk sløret deres identitet, mens 
andre medvirkende optræder genkendelige. Netop dette problem gav anledning til debat i forbindelse med Lars Engels' store dokumentarserie, Historier fra en politistation. Lars Engels skifter da også i dette program for første gang i sin lange karriere fokus: det er ikke længere de kriminelle og mennesker på samfundets bund, der er hovedpersonerne. Det er faktisk politiet og det liv, som udspiller sig på en politistation, som kommer i fokus. Dvs. det er ikke sådan, at vi - sådan som det f.eks. skete i Pigerne fra Vestre Fengsel (1992, 3 afsnit) eller Dømt til behandling (1997, 3 afsnit) - hører de kriminelles egen stemme og historie, men sådan at vi via politiets øje så at sige får et billede af Under-Danmark, som politiet er sat til at behandle. Engels taler ikke på tomandshånd med de kriminelle, og man får ikke i så høj grad deres egen baggrund og historie. Der kommer altså en slags dobbelt glas imellem os og de kriminelle, som gør, at man oplever at være placeret i en lidt mere ubehagelig, voyeuristisk position.

Lars Engels har selv beskrevet sit projekt som en art Danmarksfilm (Engels 2000), der gør status ved århundredskiftet, og som fokuserer på politiet som en institution, der egentlig mere end at være sat til at opretholde lov og orden og opklare kriminalitet laver socialt arbejde, når alle andre muligheder er udtømt, dvs. politiet er »samfundets sociale skraldemænd «. I et det samme interview i Politiken (Engels 2000) karakteriserer han sin serie som »klassisk, observerende dokumentarisme«, der lader lyd og billede tale for sig selv, og hvor der ikke er nogen forklarende tekster eller opklarende spørgsmål. Han peger også på, at han opfatter sin serie som »milevidt fra tidens grasserende tendens til at servere virkeligheden i tilberedt og afskåret form som såkaldt docu-soap«. Han karakteriserer sin udsendelse som inspireret af cinema verité eller direct cinema og som dokumentarisme, der som »den berømte flue på væggen registrerer [...] hvad der foregår«.

Når man nærmere analyserer Historier fra en politistation, hvilket i sig selv er en stor opgave i betragtning af dens længe og stofrigdom, træder der i hvert fald én tydelig forskel frem i forhold til de to ovenfor nævnte reality-serier. Engels har ikke castet sine personer, selvom valget af sted og de, der arbejder der, altid indebærer et valg og et fravalg. Det er f.eks. ikke Hørsholm Politistation, han vælger, eller en jysk landpolitistation. Så hans Danmarksbillede er i den forstand et redaktionelt valg, men når dette valg er foretaget, optager han, hvad der sker foran kameraet, uden at kunne forudse alle de personer og hændelser, der kommer på båndet. Han kan altså ikke som i fiktionen kontrollere den profilmiske virkelighed, kun den postfilmiske redaktionsproces og sammenklipning. Som vi netop har set forsøger docu-soap konceptet at kontrollere og caste den profilmiske virkelighed i højere grad, end det er normen ved både den journalistiske og den observerende dokumentar.

Engels pointerer i interviewet, at han bruger politistationen som ramme om et socialt portræt af, hvordan mennesker i Danmark i dag også har det, og ikke primært vil skildre politiet positivt eller kritisk ${ }^{5}$ : » Mit syn på politistationen og politiets arbejde bringer jeg frem i serien. Jeg har ikke lyst til på forhånd at udbasunere hvad privatmennesket Lars Engels mener. Jeg leverer beskrivelsen og ikke facit.« Samtidig tager har relativt tydeligt afstand fra det, han opfatter som den iscenesatte docu-soap og også fiktionens dramatiske repræsentation af politiets arbejde og relationen til andre mennesker og de kriminelle:

Mine programmer er hverken »Hill Street« eller »New York Blues«. Mit syn er meget forskelligt fra det, som fiktionen dyrker. Her er hverken vilde biljagter eller skarpe skud. Men bag hver eneste historie på stationen gemmer sig et menneske, og det er ham eller hende, jeg har søgt at komme ind til. Jeg er vel ude i en form for antropologisk ærinde gennem en socialrealistisk skildring fra centrum af København. (Engels 2000)

Men naturligvis er det, som Engels gengiver, ikke den rene og skære virkelighed, for den har vi ingen adgang til i fuldt omfang, selv ikke hvis man blot stillede et statisk kamera op et bestemt sted i verden. Det ville altid være netop verden set fra dette sted. Derfor er Engels' virkelighed også en redigeret og iscenesat virkelighed, men det er blot en redigering og iscenesættelse, som følger delvis andre principper end docu-soaps, og som primært ligger i den postfilmiske redigering. Men den observerende dokumentarisme og docu-soaps har på de fleste punkter meget tilfælles. Også Engels laver research på steder, lokaliteter, personer og mulige historier og konflikter, før han sætter kameraet op. Docu-soaps forsøger i højere grad end den traditionelle, observerende dokumentarisme at kontrollere den profilmiske virkelighed ved at researche og caste for at sikre figurerne gennemslagskraft og ved derefter i redigeringen drama- 
turgisk at bygge historierne op, så de rummer et forløb, som minder om fiktionen. Men også docusoaps er begrænset af det forhold, at der er tale om virkelige personer og hændelser og ikke en konstrueret virkelighed og fiktion. Forskellen mellem Engels' profilmiske research og postfilmiske redigering og de tilsvarende processer for docu-soaps er altså ikke en principiel forskel, men en konkret gradsforskel. For hvad er det for en 'virkelighed' og menneskelig historie, han fremstiller ved netop at komponere og redigere sine råfilmsoptagelser i den og den rækkefølge og ved at tage den og den person og historie med og ikke en anden?

Det første afsnit af serien, med undertitlen $D e^{-}$ tentionen, starter med en meget symbolsk scene, og det er ikke et tilfældigt valg, at Engels starter her. Som det hedder i den katolske dødsmesse: $D e$ profundis clamavi, fra dybet kalder jeg dig, Herre, så starter udsendelsen med de fordømtes fortvivlede råb: »Jeg vil ud«. Lyden er markant forstørret, og der ligger en dyb urovækkende undergrundsstøj under det hele på lydsporet, samtidig med at vi visuelt ser gennem et sløret glas, hvor ilden næsten synes at brænde og en hånd, der fortvivlet banker for at komme ud - ud af Under-Danmarks helvede. Der er tale om en markant signalering af, hvor synsvinklen og sympatien trods alt ligger, samtidig med at alle de efterfølgende mange afsnit usentimentalt beretter om politiets arbejde, også deres problemer med at bevare den professionelle ro og fatning ved mødet med hele den lange stribe af ofre, som både kalder på medfølelse og irritation, fordi der også er mange plattenslagere og professionelle svindlere. Den slags billeder går igen i andre dele af serien, f.eks. i de gentagne billeder fra de indsattes celler set via ov-cams, der netop virker som billeder af Under-Danmarks indespærrede helvede, set oppe fra politiets kontrolrum.

Både i Storbystromer og Strømer på Stenbroen er det karakteristiske en fokusering på bestemte betjente, som man kommer på fornavn med, og som bliver genkommende karakterer $i$ et reality-serie univers. Der varieres mellem sager ude i marken og livet på politistationen, og der krydsklippes mellem de forskellige narrative spor, som de enkelte afsnit er bygget op af. Hverdagsuniverset er altså både en arbejdsplads og det omgivende samfund. Det er karakteristisk for reality-serierne, at der er en overordnet journalistisk VO, der kommenterer og binder sammen. I Historier fra en politistation er personerne ikke identificeret med navns nævnelse i den indledende tekst, eller på skærmen, men kun indirekte efterhånden som vi hører personerne kalde hinanden ved navn. Her markerer den observerende dokumentarisme hos Engels både sin retoriske distance til reality-serien, og dermed tendensen til at caste politiet som karakterer, og til den journalistiske dokumentar, der altid omhyggeligt angiver sin kilde. Der er i helt bogstaveligste forstand tale om et ukommenteret univers opdelt $i$ små sekvenser, der viser udvalgte dele af den fotograferede virkelighed. Vi kan som seere registrere, at der ind imellem er blevet stillet et spørgsmål, fordi betjentene pludselig taler til kameraet, uden at der er nogen andre til stede, og i disse sekvenser kommenterer de deres arbejde eller de sager eller personer, de arbejder med. Sådan er det også i Engels' øvrige portrætter, men forskellen er her, at det i de øvrige udsendelser er de sociale ofre, der udtaler sig. Her er det politiet der udtaler sig, mens de andre betragtes: vi er virkelig med politiet på arbejde ude i virkeligheden.

Måden, der styres ind i dette arbejdsunivers og ud i den omgivende virkelighed på, er som sagt meget bevidst lavet. Efter optakten med råbet fra dybet går vi ovenpå til vagthavende, derefter kommer et titelskilt med et kort over området i baggrunden med larmen i baggrunden og et establishing shot af bygningen, hvor stationen ligger. Derefter gås der direkte in media res til morgensamlingen. Strukturen, kan man sige, er som Hill Street Blues, præcis de samme ingredienser, men i dokumentarisk form. Det er også karakteristisk, at det næste, vi ser til en klient, er et gadebillede, filmet i fugleperspektiv med både reallyd og elegisk-lyrisk underlægningsmusik. Vi ser en stofpåvirket eller sindsforvirret mand, der dingler rundt med en indkøbsvogn og tilsyneladende bare kører rundt om sig selv. En kvinde forsøger uden held at hjælpe, og senere i forløbet ser vi en patrulje, som kommer og samler ham op. De to indledningsbilleder etablerer altså en slags symbolsk-social ramme: det er de udstødtes, de gales, de fortvivledes og de kriminelles verden, der omgiver denne politistation, og den almindelige solidariske håndsrækning er suspenderet. Her må samfundets sociale skraldemænd træde til.

Det er også uhyre karakteristisk, at det politiarbejde, der beskrives, ikke er fiktionens tju-bangfærdig opklaringsarbejde. Det er det uendelige sisyfos-arbejde med de samme personer og typer, der blot kører i ring. De passerer alle revy i dette 
første program: Den alment fortvivlede kvinde, der er blevet bestjålet, og som næsten er mere optaget af at fortælle om sit privatliv end selve sagen; den småkriminelle unge, der er inde for sag nr. 43; den fortvivlede, overdoserede og desperate narkoludder; den evige jagt på de små narkohandlere og gadepushere; og forsøget på ved en mere målrettet aktion at få fat i de organiserede, udenlandske kreditkorttyve. Det er den uendelige og træge hverdag, hvor det hele går i ring, og dermed netop endnu et billede af det Under-Danmark, som Engels altid har beskrevet, om end denne gang set i politiets perspektiv. Slutningen på afsnit 1 er også karakteristisk for Engels. Hvor indledningen er den indespærredes fortvivlede røst, er afslutningen den småkriminelle vaneforbryder, der kører til forvaring og dom, og mens underlægningsmusikken igen sætter ind, lukker porten sig med et tydeligt smæk bag ham. Her lades alt håb ud - det hele går videre.

\section{Den medialiserede kriminalitet: Medie- og offentlighedsperspektiver}

Som gennemgangen demonstrerer, er der tydelige forskelle i æstetik, retorik og synsvinkel i de forskellige reality programmer om politiet og kriminalitet. På den ene side reality-magasiner, som i det væsentlige journalistisk bruger rekonstruktioner af kriminelle sager til dels at skabe samme oplevelse og spænding som ved en fiktionskrimi, men som samtidig i direkte samarbejde med seerne skaber en interaktiv lænestolsoffentlighed for private angivere og 'detektiver'. Graden af iscenesættelse af den journalistiske rolle og studiet og af de rekonstruerede indslag viser markante forskelle. På den anden side reality-serier, som caster politiet og almindelige mennesker $\mathrm{i}$ en realistisk fortælling fra hverdagen, med indbygget klar dramaturgisk styring, hvor oplysning består i oplevelse af en arbejdsplads og den omgivende virkelighed, men hvor iscenesættelsen og den overordnede journalistiske diskurs indgår en symbiose. Til forskel herfra er Engels tro mod den observerende dokumentarismes mindre iscenesatte og mere ukommenterede virkelighedsgengivelse, men dog med en tydelig bearbejdning og indbygning af symbolske perspektivmarkører.

Trods forskellene er det symbiotiske forhold til politiet som institution et genkommende problem i alle denne type kriminal reality-programmer. Faren består for en ulegitim afhængighed mellem politiet og tv-stationen, hvor den kritiske journalistiske funktion går tabt på grund af et samarbejde, der skaber afhængighed. Selvom programmerne tolkes som samfundsnyttig oplysning om kriminalitet til borgerne, og som aktivering af det civile samfunds fællesskab mod aktiviteter, som truer det, så vil sammenblanding af politidiskurs og journalistisk diskurs i en dramatiseret montage uden tvivl have afsmittende virkning på seernes opfattelse af relationen mellem medier og politi. Samtidig er det ofte ganske bestemte kriminelle sager, der sættes i fokus, og hvis betydning i det samlede billede kan forvrænge de rigtige virkelighedsproportioner og selve opfattelsen af denne kriminalitets betydning og udbredelse. Der er således ingen tvivl om, at hyppige seere af disse programmer vil have en opfattelse af, at mord, røverier og voldtægter er mere dominerende, end de faktisk er, og at angsten for den blinde vold mellem personer, som ikke har nogen relation til hinanden, overdrives (jf. f.eks. Dobash, Schlesinger et. al. 1998:52ff).

Dertil kommer at Politiet også er blevet mere aktive i deres pressearbejde og dermed bevidst tænker i, hvordan medieeksponeringen bedst kan tilrettelægges, så den efterlader et positivt billede. Et par karakteristiske udtalelser fra to pressetalsmænd fra henholdsvis Københavns Politi og Rigspolitiet viser denne nye bevidsthed:

Man kan ikke generelt styre pressen, det er naivt at tro - men som vi siger: Knus dem med kærlighed (Per Larsen, Københavns Politi). Ved at koordinere udtalelserne sikrer man sig, at det er det samme budskab, der kommer ud over hele linjen (Søren Kragh Pedersen, Rigspolitiet). (citeret efter Thomas Hoffmann, 2001)

Spillet mellem medierne og de institutioner, som medierne også er sat til at være kritiske vagthunde for på borgernes vegne, bliver altså mere kompliceret og mudret i sig selv og mudres yderligere af hybridgenrer som disse, der baserer sig på ukritisk samarbejde og tilsyneladende ukritisk beskrivelse af politiet.

Man kan betragte hele den observerende dokumentarismes stærke udvidelse af virkelighedsbilledet til hverdagen og det private og til sider af samfundslivet, som ikke ofte skildres på tv, som en demokratisering, og man kan altså også se en ræk- 
ke reality-tv former som forlængelser af denne tendens, om end mere kommercielt iscenesat. Men der er heller ingen tvivl om, som bl.a. John Corner har peget på (Corner 2000), at denne transformering af det offentlige rum også har skabt en modsætning og spænding mellem programmer, der rummer mere klassiske, journalistiske diskurser, og derfor kan komme i klemme i en populistisk bevægelse mod reality-tv og mere oplevelsespræget æstetik. Det er denne problematik, der rejses i en artikel i Politiken, »TV for tænkere«(Rothenborg 2000), som på basis af interviews med branchefolk bag den grundige, kritiske og dybdeborende journalistiske dokumentar taler om en krise for mere tænksomt og kritisk tv. Den observerende hverdagsdokumentar og især de meget billigere reality-tv formater truer eksistensen af den dyrere, journalistiske dokumentar, også fordi reality-tv tilsyneladende formår at skaffe seertallene. Men den blotte fremlæggelse af virkeligheden, eller den dramatiserede oplevelse af den, giver ikke i sig selv social og politisk indsigt og forståelse. Det kræver, at tingene bliver sat ind i en forståelses- og forklaringsramme, som konfronterer forskellige synspunkter og dermed skaber en dialog. Den observerende dokumentarisme og realitytv kan ikke stå alene.

Udover problemet med den manglende forklaringsramme og det kritiske perspektiv, og problemet med den type af kriminalitet, som afbildes, og det symbiotiske forhold til politiet, som gør os til systemets medvidere og medspillere, er der også problemet med overskridelse af private og etiske grænser. Både reality-tv programmer og Lars Engels' programmer er bygget på angiveligt positivt samvirke og tilsagn fra alle medvirkende. Men det er ikke uproblematisk at gå ud fra, at personer fanget i disse situationer og i den mentale tilstand ofte ikke kan overskue det samtykke, de måtte give. På den ene side står behovet for hele tiden at udvide vores virkelighedsbillede og komme tættere på og udover de grænser og barrierer, der eksisterer for, hvilke dele af virkeligheden man kan skildre. Megen fiktionskunst har også i tidens løb provokeret og vakt forargelse ved at overskride disse grænser. På den anden side er der ikke bare etisk carte blanche, der er også ofre og individer at tænke på. Det er en vanskelig balancegang, netop i dokumentarismen, hvor det ikke er konstruerede personer og fiktive universer, der skildres, men naboen lige henne om hjørnet.

De audiovisuelle medier muliggør i sig selv en langt stærkere interaktion mellem de forskellige sfærer og institutioner og en langt større synliggørelse af det private bag det offentlige og inddragelse af hverdagen (se Zoonen 1998 og Wieten 1998). Og i netværkssamfundet er det kontrollerede offentlige rum på godt ond ondt forsvundet: Kommunikationsnetværk kan dannes omkring alt og på tværs af alle grænser, og det er også langt nemmere for det enkelte individ at eksponere sig selv, at gøre det private til en offentlig scene, sådan som det sker, når private laver deres egen website med webcam billeder fra deres hjem. Big Brother som tv-fænomen er en ironisk netværkssamfundsomvending af Orwels dystopiske metafor. Det er ikke samfundet, der overvåger den enkelte, men de enkelte der stiller sig til skue for individuel og kollektiv nyfigenhed. Det er den samme dybtliggende fascination ved det forbudte, den samme nyfigenhed overfor det private og det tabubelagte, som gør reality-tv om kriminalitet til stærkt udbredt og populært tv.

\section{Noter}

1 Jf. f.eks. kritikken af Rejseholdets afsnit 13, som brugte den såkaldte Wæver-sag som baggrund, hvilket førte til et sagsanlæg fra familien (Berlingske Tidende, 03.04.01, s. 2). Tv-drama chef Ingolf Gabold har i Informations kronik (Kunst? - Nå nej det er jo fjernsyn, 27.04.01) helt generelt forsvaret brugen af autentiske historier $\mathrm{i}$ fiktionen. Han ser generelt indvendingen som et udtryk for, at tv ikke anerkendes som rigtig kunst, som naturligvis gerne må bruge autentiske historier frit.

2 Den genreopdeling og beskrivelse, som foretages her, er min egen, men en række af de kategorier og begreber, der benyttes, og et par af de genrer, der beskrives, henter inspiration hos Carl Plantinga (1997) og Nichols (1991), som imidlertid begge mest taler om film og derfor ikke uden videre kan overføres til tv.

3 Denne Dokusoap-bibel er udarbejdet i 2000 i DR's fakta-afdeling, nærmere bestemt Hverdagsredaktionen, som har Dorthe Carlsen som redaktionschef. Dokumentet har ikke en angivet forfatter.

4 If. telefonisk samtale med Christian Andersen, d. 15.06.01, er programmet lavet før, den såkaldte DRDokusoap-Bibel blev lavet, og uden noget dansk forbillede. CA havde dog set nogle engelske docu-soaps, men ville gerne lave noget der kom lidt dybere, og han betegner det selv klart som en docu-soap og en forløber for Biblens principper.

5 Engels' portræt af Station 1 blev under selve udsendelsen sat $\mathrm{i}$ relief af to sager, hvor betjente fra stationen blev anklaget for vold i forbindelse med behandling af klienter og også af en sag, hvor en kollega, som ville vidne mod en anden politibetjent, blev truet og overfaldet. Sådanne kritiske sager mod politiet selv 
kommer ikke rigtig til orde hos Engels, når der ses bort fra klienter, som af og til direkte henvender sig til kameraet og anklagende taler om politiovergreb.

\section{Litteratur}

Bondebjerg, Ib (2002, in print): »Verden ifølge Lars Engels«, in Jens F. Jensen: Analyser af tv 1-2. Medusa.

Bondebjerg, Ib (2002 a): »The Mediation of Everyday Life. Genre, Discourse and Spectacle in Reality-TV.«, in Anne Jerslev (red.): Realism and Reality in Film and Media. Northern Lights 2002. Film and Media Studies Yearbook, København: Museum Tusculanum Press.

Bondebjerg, Ib (2000): »I dialog med den danske virkelighed - TV2's dokumentariske profil«, in Henrik Søndergaard, m.fl.: TV2 på skermen. Samfundsfagslitteratur.

Bondebjerg, Ib (1996/2000a): »Public Discourse - Private fascination«, in Media, Culture \& Society, 18:1 27-45, optrykt i Newcombe (ed): Television the Critical View. 6th. ed. Oxford University Press, 2000.

Corner, John (2000): »Documentary in a Post-Documentary Culture. A note on Forms and their Functions." (Webpublikation: http://www.lboro.ac.uk/research/ changing.media/index.html)

Ekström, Mats (2000): »Information, storytelling and attractions.«, in Media Culture $\mathcal{E}^{2}$ Society, vol. 22, no. 4.

Engels, Lars (2000): »Station 1 Danmark«, in Politiken, 14.10.00, interview af Niels Steensgaard.

Fishman, Mark \& Gray Cavendar (eds) (1998): Entertaining Crime: Television Reality Programmes. New York: Aldine de Gruyter.

Hill, Annette (2000): »Crime and Crisis: British Reality TV in Action.«, in Edw. Buscombe (ed): British Television. A Reader. Oxford University Press.
Hill, Annette (2000): »Fearful and safe: Audience response to British Reality Programming.« in Izod, et al. (eds): From Grierson to Docu-Soap. University of Luton Press.

Hoffmann, Thomas (2001): »Ingen kritik men masser af sager/Knus dem med kærlighed.«, 2 artikler i Information under temaet »Politiet og Pressen«, 06.06.01.

Kilborn, Richard (1994): »»How real can you get«. Recent Developments in »Reality« Television.«, in European Fournal of Communication, vol. 9.

Langer, John (1998): Tabloid Television. Routledge.

Nichols, Bill (1991): Representing Reality, Indianapolis: Indiana University Press.

Plantinga, Carl (1997): Rhetoric and Representation in Nonfiction Film, Cambridge: Cambridge Uníversity Press.

Rothenborg, Michael (2000): »TV for tænkere.«, in Politiken, 26.11.00.

Schlesinger, Philip \& H Tumber (1994): Reporting Crime: The Media Politics of Criminal fustice, Oxford: Clarendon Press.

Søndergaard, Henrik og Stig Hjarvard (1988): Narsyn på fjernsyn. Weekend TV og Kanal 2, C.A. Reitzel.

Søndergaard, Henrik (2002, in print): »Reality TV«, in Jens F. Jensen: Analyser af to 1-2. Medusa.

Wieten, Jan (1998): "Reality Television and Social Responsibility Theory.«, in Brandts, Hermes \& van Zoonen (red.): The Media in Question. Popular Cultures and popular Interests, London: Sage.

Zoonen, Lisbet (1998): »The Ethics of Making private Life Public.«, in Brandts, Hermes \& van Zoonen (red.): The Media in Question. Popular Cultures and popular Interests, London: Sage.

Ib Bondebjerg er professor på Institut for Film- og Medievidenskab ved Københavns Universitet. 